\section{Influence of Thermal Cycles Number on Bond Strength of Metallic Brackets to Ceramic}

José Eliú Pereira Jurubeba ${ }^{2}$, Ana Rosa Costa ${ }^{1}$, Lourenço Correr-Sobrinho', Carlos Alberto Malanconi Tubel ${ }^{2}$, Américo Bortolazzo Correr ${ }^{1}$, Silvia Amélia Vedovello2 ${ }^{2}$ Marcus Vinicius Crepaldi ${ }^{3}$, Mário Vedovello Filho ${ }^{2}$

\author{
'Department of Restorative \\ Dentistry, Dental Materials \\ Division, Piracicaba Dental School, \\ UNICAMP - Universidade Estadual \\ de Campinas, Piracicaba, SP, Brazil \\ ${ }^{2}$ Department of Orthodontics, \\ Graduate Program in Orthodontics, \\ UNIARARAS - Universidade \\ de Araras, SP, Brazil \\ ${ }^{3}$ Institute of Higher Education, \\ FAIPE, Faculdade de Tecnologia \\ do Instituto de Pesquisa e \\ Ensino, Cuiabá, MT, Brazil
}

Correspondence: Lourenço CorrerSobrinho, Avenida Limeira, 901, 13414-903, Piracicaba, SP, Brasil. Tel: +55-19-2106-5345. e-mail:

\begin{abstract}
The aim of this study was to evaluate the effect of different number of thermal cycles on the shear bond strength (SBS) of metallic orthodontic brackets bonded to feldspathic ceramic by a composite resin. Twenty-five ceramic cylinders were etched with $10 \%$ hydrofluoric acid for $60 \mathrm{~s}$ and received two layers of silane. Brackets were bonded to the cylinders using Transbond XT and assigned to 5 groups $(n=5)$ : Group 1 - Control group (without thermal cycling); Group 2 - 500 thermal cycles; Group 3 - 5,000 thermal cycles; Group $4-7,000$ thermal cycles and Group 5 - 10,000 thermal cycles. Light-activation was carried out by Radii Plus LED. SBS testing was carried out after $24 \mathrm{~h}$ of storage in deionized water and thermal cycling $\left(5 / 55^{\circ} \mathrm{C}\right.$ and $30 \mathrm{~s}$ dwell time). Five brackets were bonded to each cylinder, totalizing 25 brackets for each group. Data were submitted to one-way ANOVA and Tukey's test $(\alpha=0.05)$. The Adhesive Remnant Index (ARI) was evaluated at $8 \times$ magnification. The SBS (MPa) of control group (9.3 \pm 0.8$), 500(9.0 \pm 0.7)$ and $5,000(8.4 \pm 0.9)$ thermal cycles were significantly higher than those after 7,000 $(6.8 \pm 0.6)$ and $10,000(4.9 \pm 1.0)$ thermal cycles $(p<0.05)$. The ARI showed a predominance of Scores 0 (adhesive failure) prevailed in all groups, as shown by the ARI, with increased scores 1 and 2 (mixed failures) for control group and 500 thermal cycles. In conclusion, thermal fatigue may compromise the bonding integration between metallic brackets and ceramic restorations. For in vitro testing, use of at least 7,000 cycles is advised to result in significant fatigue on the bonding interface.
\end{abstract}

\section{sobrinho@fop.unicamp.br}

\section{Introduction}

In the last years, use of restorative materials like dental ceramic has increased as result of their optimum esthetic and mechanical properties (1), and as substrates for bonding of brackets in clinical situations (2). Bonding to ceramic is usually achieved after etching with hydrofluoric acid (3).

The ceramic/composite and composite/tooth structure interfaces have been addressed in clinical studies as factors for ageing processes (4) to determine the clinical long-term success. Previous study showed that restorations submitted to oral environment are exposed to thermal, physical and chemical changes due to contact with drinks and food (5). The bond among orthodontic brackets, composite and ceramic is an important factor for durability and clinical success. In vitro orthodontic test of bond strength provides a guide for selecting bracket-adhesive combinations. The bonding of brackets to the tooth is commonly evaluated by tensile or shear bond strength tests. The shear bond strength test is the most used to evaluate the bonding of brackets to the tooth $(2,3)$. It is most recommended because it reproduces the stresses caused at the bonding resin/enamel and bonding resin/bracket interfaces during alignment, leveling and sliding movements in the orthodontic treatment. The durability may be influenced due to heavy forces produced by archwire (2), the action of water-saliva storage (6), thermal and mechanical cycling test to simulate the oral conditions prior to mechanical tests $(5,7)$.

Due to temperature changes, thermal cycling tests produce alternate stresses at the interface of the two or more materials(9). Besides, the difference in the thermal expansion coefficients of both materials may cause adhesive loss from temperature variations (7). In orthodontics, the number of thermal cycles varies from 500 to 6,000 $(5,8,10,11)$. However, the literature is still inconclusive regarding the number of thermal cycles in orthodontics.

Thus, the aim of this study was to evaluate the effect of different number of thermal cycles on the bond strength of metallic orthodontic brackets to feldspathic ceramic using a composite resin. The null hypothesis was that the number of thermal cycles would not influence the bond interaction between metallic orthodontic brackets and feldspathic ceramic. 


\section{Material and Methods}

Twenty-five glazed feldspathic ceramic cylinders (Certec Advanced Ceramics, Barueri, SP, Brazil), $13 \mathrm{~mm}$ diameter and $20 \mathrm{~mm}$ high were used in this study. The surfaces were cleaned using a rubber cup (KG Sorensen, Cotia, $\mathrm{SP}$, Brazil) and non-fluoridated pumice-water slurry (S.S. White, Petropolis, RJ, Brazil) for $20 \mathrm{~s}$, rinsed with air-water spray for $20 \mathrm{~s}$ and air-dried for $20 \mathrm{~s}$. The rubber cup was replaced for each cylinder. The cylinders were etched with 10\% hydrofluoric acid gel (Dentsply Caulk, Milford, DE, USA) for $60 \mathrm{~s}$, rinsed with air-water spray for $30 \mathrm{~s}$ and airdried for $30 \mathrm{~s}$. On all cylinders were applied two layers of RelyX Ceramic Primer (3M ESPE, St. Paul, MN, USA) silane and dried for $60 \mathrm{~s}$. Afterwards, stainless steel standard maxillary premolar brackets (Abzil, 3M do Brasil Ltda, São Jose do Rio Preto, SP, Brazil) were firmly bonded to the ceramic cylinder's surface using bonding composite resin (Transbond XT; 3M Unitek, Monrovia, CA, USA), following the manufacturers' instructions. All excess of composite resin was removed using a microbrush.

The light-activation was carried out using light emitting diodes (LED; Radii Plus; SDI Limited, Bayswater, Victoria, Australia) with 4 exposures of $10 \mathrm{~s}$ (one in each side of the bracket), for a total exposure time of $40 \mathrm{~s}$. When five brackets were bonded to the same ceramic cylinder, a punch-holed strip of black adhesive tape was used to avoid light exposure to adjacent brackets, restricting the polymerization light to the specimen being bonded $(2,3,11)$. The irradiance of $1,100 \mathrm{~mW} / \mathrm{cm}^{2}$, was measured with a power meter (Ophir Optronics Inc., Danvers, MA, USA) and a computer-controlled spectrometer (USB2000; Ocean Optics, Dunedin, FL, USA) with an energy density of $48 \mathrm{~J} / \mathrm{cm}^{2}$.

After light-activation, all the specimens were stored in deionized water at $37{ }^{\circ} \mathrm{C}$ for $24 \mathrm{~h}$ and divided into 5 groups $(n=5)$ : Group 1 - Control group (without thermal cycles); Group 2 - 500 thermal cycles; Group 3 - 5,000 thermal cycles; Group 4 - 7,000 thermal cycles; and, Group 5 - 10,000 thermal cycles. After this, the specimens of groups $(2,3,4$ and 5$)$ were submitted respectively to 500 (8), 5,000, 7,000 (2) and 10,000 thermal cycles in a thermal cycler (MSCT 3; Marnucci ME, São Carlos, SP, Brazil) with deionized water between $5{ }^{\circ} \mathrm{C}$ and $55^{\circ} \mathrm{C}$ (dwell time of 30 s) and transfer time of $10 \mathrm{~s}$ between baths.

After storage time and thermal cycling, a mounting jig was used to align the ceramic-bracket interface parallel to the testing device. The shear bond test was made in a universal mechanical testing machine (Model 4411; Instron, Canton, MA, USA), the load applied by a knife-edged rod at a crosshead speed of $1.0 \mathrm{~mm} / \mathrm{min}$ until failure. The shear bond strength values were calculated in MPa. Data were statistically analyzed using one-way ANOVA (number of thermal cycles) and Tukey's test ( $\alpha=0.05)$.

The bracket and ceramic surfaces were observed under an optical microscope (Olympus Corp, Tokyo, Japan) at $8 x$ magnification after shear bond test. The Adhesive Remnant Index (ARI) was used to classify the failure modes as follows (12): score 0: no composite resin left on the ceramic; score 1: less than half the composite resin left on the ceramic; score 2: more than half the composite resin left on the ceramic; and score 3: all composite resin left on the ceramic, with a clear impression of the bracket mesh.

\section{Results}

The shear bond strength mean values are shown in Figure 1. Significant influence of thermal cycles number $(\mathrm{p}<0.001)$ was observed. The mean bond strength of control group, 500 and 5,000 thermal cycles was significantly higher than for 7,000 and 10,000 thermal cycles $(p<0.001)$. The 7,000 thermal cycles was significantly higher than 10,000 $(p<0.001)$. No significant differences in bond strength were found between the control group and 500 thermal cycles ( $p=0.921)$, control group and 5,000 thermal cycles $(p=0.054)$ and 500 thermal cycles and 5,000 thermal cycles $(p=0.314)$. Figure 2 shows the results for ARI. Despite the large number of 0 scores (adhesive failure) observed for the specimens in all groups, there was increase of scores 1 and 2 (mixed failures) for control group and 500 thermal cycles.

\section{Discussion}

The clinical success and long-term durability of the bond strength between orthodontic brackets and the ceramic surface using composite resin may be influenced by several factors, such as thermal cycling, fatigue, artificial ageing and mechanical properties of composite resin, silane and adhesive bonding (11). The quality and durability of this bond is determined by the specific treatment used to produce chemical and micromechanical retention to the ceramic material (13) and bonding mechanisms between bracket/bonding materials (2). Bracket debonding during

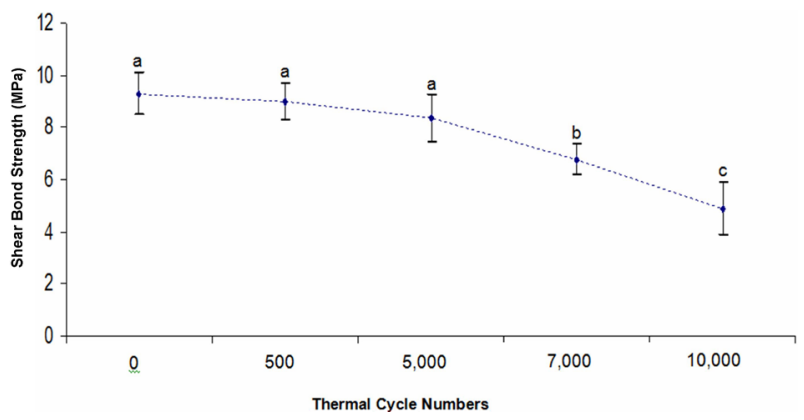

Figure 1 . Mean shear bond strength $(\mathrm{MPa}) \pm$ standard deviation of the evaluated groups. Different letters indicate significant difference for values of thermal cycling according to the Tukey's test $(\mathrm{p}<0.05)$. 
orthodontic treatment is commonly reported at clinics. Repositioning of brackets is difficult and may interfere in the positioning of the tooth, demanding from the clinicians additional mechanisms to achieve the best position of the teeth at the end of the orthodontic treatment. Other undesirable consequences of the bracket debonding are increase of chair-time and cost of the orthodontic treatment.

Some studies have used artificial ageing methods in long-term water storage to verify the durability of bracket bonding $(6,11)$. In this study, thermal cycling was used to check if temperature changes influence the reduction of the bond strength between bracket and bonding material. The reduction of mechanical properties of the bond resin may result from the abrupt fall of temperature on bonded materials with different expansion coefficients and thermal conductivities, causing thermal stress at the interface (7) or by continuous action of water on the orthodontic bracket/ bonding resin interface. Thermal cycling may produce interface degradation and debonding, which changes the stress/strain levels transferred to the interface (14) and reducing the bond strength by hydrolytic degradation of the interface components (15). A previous study showed E that the durability of the bond strength between a silanetreated ceramic surface and the resin cement decreased with thermal cycling or water storage (16). Some studies have shown that, depending on the type of the silane, thermal cycling may have a significant effect on bond strength reduction of the ceramic and resin interface $(17,18)$. Previous studies showed that the application of silane followed by resin cement was partially effective in water storage conditions or after thermal cycling for decrease of the bond strength (19).

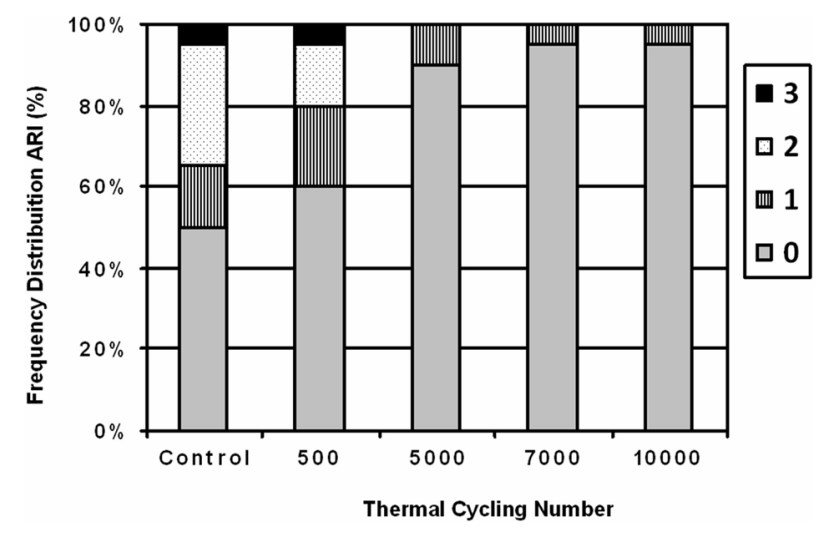

Figure 2. Frequency distributions (\%) of the Adhesive Remnant Index (ARI) scores for all groups. Score 0: no composite resin left on the ceramic; Score 1: less than half the composite resin left on the ceramic; Score 2: more than half the composite resin left on the ceramic and Score 3: all composite resin left on the ceramic, with a clear impression of the bracket mesh.
In this study, the data showed that there was significant difference when the specimens were submitted up to 7,000 thermal cycles. Thus, the tested hypothesis was rejected. The specimens submitted to 7,000 and 10,000 thermal cycling have a bond strength loss of $27.3 \%$ and $46.7 \%$, respectively. These findings are in agreement with a previous study, which also found that thermal cycling up to 7,000 significantly reduced the bond strength (2). That study analyzed thermal cycling associated to different light sources, silane and feldspathic ceramic, while this study used only thermal cycling. However, they disagree with other studies, which found no significant difference in bond strength after thermocycling $(5,11)$. The lack of difference may be explained by the fact that these studies used a smaller number of cycles. However, some studies showed that the structures involved are small, then the thermal changes are moderately rapid (20). Thus, long resting periods appear to be unnecessary, allowing accelerated simulation $(21,22)$. According to Gale and Darvell (5), the number of thermal cycles used in several studies varied from 1 to $1,000,000$ with a mean about of 10,000 and median of 500 cycles. Other studies suggested that 6,000 thermal cycles would correspond to 5 year clinical service $(9,23,24)$. In this study, the 500 , $5,000,7,000$ and 10,000 thermal cycles were selected and then extrapolated for approximately $0.42,4.16,5.83$ and 8.33 years of clinical service, respectively. Thus, probably in clinical service below 5.85 years the orthodontic treatment could be carried out without compromising the bracket's adherence. Despite great variations in temperature and their tolerance in vivo, thermal cycling simulation is required to allow comparison of materials and procedures between reports (5). The thermal gradient and rate of temperature change also control the mechanical stresses by the effects of differential thermal conductivity (5).

Reynolds (25) suggests that bond strength values in the range of 6 to $8 \mathrm{MPa}$ are adequate for orthodontic forces in the oral environment. In the current study, bond strength values lower than $6 \mathrm{MPa}$ were obtained for groups where the specimens were submitted to 10,000 thermal cycles. Thus, care should be taken only when the orthodontic treatment is long.

ARI values indicated predominance of debonding failures with score 0 , when no bonding composite resin on the ceramic surface was observed. A predominance of score 0 observed in all groups may be clinically advantageous because there is less composite resin to remove from the ceramic surface after bracket debonding.

In summary, the current study demonstrated that the thermal fatigue may compromise the bonding integration between metallic brackets and ceramic restorations. For in vitro testing, at least 7,000 cycles are advised to obtain 
significant fatigue on the bonding interface. A limitation of the present study was that only one bonding material was used. Further studies should analyze the effect of different bonding materials.

\section{Resumo}

0 objetivo neste estudo foi avaliar o efeito de diferentes números de ciclos térmicos na resistência da união de braquetes metálicos à cerâmica feldspática usando resina composta. Vinte e cinco cilindros de cerâmica foram condicionados com ácido fluorídrico a $10 \%$ por $60 \mathrm{~s} \mathrm{e}$ duas camadas de silano. Braquetes foram fixados nos cilindros usando Transbond XT e depois separados em 5 grupos $(n=5)$ : Grupo 1 - Grupo Controle (sem ciclagem térmica); Grupo $2-500$ ciclos térmicos; Grupo 3 - 5.000 ciclos térmicos; Grupo $4-7.000$ ciclos térmicos e Grupo 5 10.000 ciclos térmicos. A fotoativação foi realizada com aparelho LED Radii Plus. 0 ensaio de resistência de união ao cisalhamento foi realizado após armazenagem por $24 \mathrm{~h}$ em água deionizada ou após a ciclagem térmica ( $5 \% 55^{\circ} \mathrm{C}$, com banhos de $30 \mathrm{~s}$ cada). Cinco braquetes foram fixados em cada cilindro, totalizando 25 bráquetes por grupo. Os dados foram submetidos à análise de variância de um fator e ao teste de Tukey $(\alpha=0,05)$. 0 Índice de Remanescente Adesivo (IRA) foi avaliado com aumento de 8x. Os valores de resistência (MPa) dos grupos controle $(9,3 \pm 0,8), 500(9,0 \pm 0,7)$ e $5.000(8,4 \pm 0,9)$ ciclos térmicos foram significantemente maiores do que os grupos submetidos à $7.000(6,8 \pm 0,6)$ e $10.000(4,9 \pm 1,0)$ ciclos térmicos $(p<0,05)$. 0 IRA mostrou predominância do escore 0 para todos os grupos, com aumento de escores 1 e 2 para os grupos controle e submetidos a 500 ciclos térmicos. Em conclusão, a fadiga térmica pode comprometer a união entre os braquetes metálicos e as restaurações cerâmicas. Para testes in vitro, o uso de pelo menos 7.000 ciclos é recomendado para determinar fadiga significante na interface de união.

\section{References}

1. Sundfeld Neto D, Naves $L Z$, Costa $A R$, Correr AB, Consani $S$, Borges $G A$, et al.. The effect of hydrofluoric acid concentration on the bond strength and morphology of the surface and interface of glass ceramics to a resin cement. Oper Dent 2015;40:470-479.

2. Abreu Neto $H F$, Costa $A R$, Correr $A B$, Vedovello $S A$, Valdrighi $H C$, CorrerSobrinho $L$, et al.. Influence of light source, thermocycling and silane on the shear bond strength of metallic brackets to ceramic. Braz Dent J 2015;26:685-688.

3. Gonçalves PR, Moraes RR, Costa AR, Correr AB, Nouer PR, Sinhoreti MA et al.. Effect of etching time and light source on the bond strength of metallic brackets to ceramic. Braz Dent J 2011;22:245-248.

4. Guess PC, Selz CF, Steinhart YN, Stampf S, Strub JR. Prospective clinical split-mouth study of pressed and CAD/CAM all-ceramic partialcoverage restorations: 7-year results. Int J Prosthodont 2013;26:21-25.

5. Gale MS, Darvell BW. Thermal cycling procedures for laboratory testing of dental restorations. J Dent 1999;27:89-99.

6. Costa $A R$, Correr $A B$, Consani $S$, Giorgi MCC, Vedovello AS, Vedovello Filho $M$, et al.. Influence of water storage and bonding material on bond strength of metallic brackets to ceramic. Braz Dent J 2015;26:503-506.

7. Vásquez V, Ozcan $M$, Nishioka $R$, Souza $R$, Mesquita $A$, Pavanelli $C$.
Mechanical and thermal cycling effects on the flexural strength of glass ceramics fused to titanium. Dent Mater J 2008;27:7-15.

8. International Organization for Standardization - ISO. Dental materials. Testing of adhesion to tooth structure. Technical Specification. 2nd edition. ISO/TS 11405:2003

9. Fischer J, Zbären C, Stawarczyk B, Hämmerle CH. The effect of thermal cycling on metal-ceramic bond strength. J Dent 2009;37:549-553.

10. Trites B, Foley TF, Banting D. Bond strength comparison of 2 selfetching primers over a 3-month storage period. Am J Orthod Dentofacial Orthop 2004;126:709-716.

11. Yuasa T, lijima M, Ito $S$, Muguruma T, Saito T, Mizoguchi I. Effects of long-term storage and thermocycling on bond strength of two selfetching primer adhesive systems. Eur J Orthod 2010;32:285-290.

12. Artun J, Bergland S. Clinical trials with crystal growth conditioning as an alternative to acid-etch enamel pretreatment. Am J Orthod 1984;85:333-340.

13. Della Bona A, Shen C, Anusavice KJ. Work of adhesion of resin on treated lithia disilicate-based ceramic. Dent Mater 2004;20:338-344.

14. Yang $R$, Arola D, Han Z, Zhang X. A comparison of the fracture resistance of three machinable ceramics after thermal and mechanical fatigue. J Prosthet Dent 2014;112:878-885.

15. De Munck J, Van Landuyt $K$, Peumans $M$, Poitevin $A$, Lambrechts $P$, Braem $M$, et al.. A critical review of the durability of adhesion of tooth tissue: methods and results. J Dent Res 2005;84:118-132.

16. Kamada $K$, Yoshida $K$, Atsuta M. Effect of ceramic surface treatments on the bond of four resin luting agents to a ceramic material. J Prosthet Dent 1998;79:508-513.

17. Guarda $G B$, Correr $A B$, Gonçalves $L S$, Costa $A R$, Borges $G A$, Sinhoreti $M A$, et al.. Effects of surface treatments, thermocycling, and cyclic loading on the bond strength of a resin cement bonded to a lithium disilicate glass ceramic. Oper Dent 2013;38:208-217.

18. Hoosmand $T$, van Noort $R$, Keshvad A. Bond durability of the resinbonded and silane treated ceramic surface Dent Mater 2002;18:179188.

19. Salvio LA, Correr-Sobrinho L, Consani S, Sinhoreti MA, de Goes $M F$, Knowles JC. Effect of water storage and surface treatments on the tensile bond strength of IPS Empress 2 ceramic. J Prosthodont 2007:16:192-199.

20. Plant CG, Jones DW, Darvell BW. The heat evolved and temperatures attained during setting of restorative materials. Br Dent $J$ 1974;137:233-238

21. Crim GA, Mattingly SL. Evaluation of two methods for assessing marginal leakage. J Prosthet Dent 1981;45:160-163.

22. Rossomando KJ, Wendt SL Jr. Thermocycling and dwell times in microleakage evaluation for bonded restorations. Dent Mater 1995;11:47-51.

23. Leibrock $A$, Degenhart $M, B e h r M$, Rosentritt $M$, Handel $G$. In vitro study of the effect of thermo- and load-cycling on the bond strength of porcelain repair systems. J Oral Rehabil 1999;26:130-137.

24. Pröbster L, Maiwald U, Weber H. Three-point bending strength of ceramics fused to cast titanium. Eur J Oral Sci 1996;104:313-319.

25. Reynolds IR. A review of direct orthodontic bonding. Br J Orthod 1975;2:171-178. 